\title{
THE USE OF STRUCTURAL ANALYTICAL SINTETIK ( SAS) METHOD TO IMPROVE STUDENTS' ABILITY IN WRITING AND READING AT THE SECOND GRADE STUDENTS OF SD NEGERI 06 PERAWANG BARAT
}

\author{
PARMIAS
}

Volume 2 Nomor 1

JIPS ISSN: 2579-5449

\begin{abstract}
This research is a Classroom Action Research (PTK). Conducted collaboratively between researchers, observers and subjects studied. The main objective of this research is to improve the ability of learners writing and reading grade 2 on ability wrote the entry through the method of SAS. The subjects of this study were all students of class II consisting of 26 students, with the composition of 13 women and 13 students. The implementation of this research was conducted in the odd semester of the 2015/2016 school year. The process of this research is conducted two cycles; the allocation of each cycle is two hours of lesson consists of four main actions namely planning, implementation, observation, and reflection.

Based on observation and Visible data processing enhancement Understanding the Evidence Quantitative: Cycle 1: The number of those who reached KKM 6 students (44.44\%), the lesser value of the KKM 20 children $(55.55 \%)$ and Cycle 2: the score of student is reaching KKM 26 students (97.22\%). There is an increase of $52.78 \%$ on Cycle 2 (learning with Method Structural Analytic Synthetic). Qualitative evidence: Student could seen from Increase value students as more interest in doing Learning 2. Students more brave in Expression 3. Lecture more Natural and Fun. That matter Show that use Method Structural Analytic Synthetic) can Improve ability of the beginning of writing. This Means Hypothesis proven.
\end{abstract}

\section{$\overline{\text { PENGGUNAAN METODE STRUKTURAL ANALITIK SINTETIK (SAS) }}$ UNTUK MENINGKATKAN KEMAMPUAN MENULIS DAN MEMEMBACA PADA SISWA KELAS 2 SD NEGERI 06 PERAWANG BARAT}

\begin{abstract}
ABSTRAK
Penelitian ini merupakan Penelitian Tindakan Kelas(PTK). Dilaksanakan secara kolaboratif antara peneliti, observer dan subyek yang diteliti. Tujuan utama dalam penelitian ini adalah untuk meningkatkan kemampuan Menulis

dan membaca peserta didik kelas 2 pada kemampua menulis permulaan melalui metode SAS. Subyek penelitian ini adalah seluruh peserta didik kelas II yang terdiri dari 26 peserta didik, dengan komposisi perempuan 13 peserta
\end{abstract}


didik dan laki-laki 13 peserta didik. Pelaksanaan penelitian ini dilakukan pada semester ganjil tahun pelajaran 2015/2016. Proses penelitian ini dilaksanakan dua siklus, alokasi setiap siklus adalah dua jam pelajaran terdiri dari empat tindakan utama yaitu perencanaan, pelaksanaan, observasi, dan refleksi.

Berdasarkan observasi dan pengolahan data terlihat peningkatan pemahaman yang Bukti kuantitatif : Siklus pertama : nilaianak yang mencapai KKM 6anak (44,44\%), nilaianak yang kurangdari KKM 20 anak $(55,55 \%)$ dan Siklus kedua: nilai anak yang mencapai KKM 26 anak $(97,22 \%)$. Terjadi peningkatan $52,78 \%$ pada siklus kedua (pembelajaran dengan Metode Struktural Analitik Sintetik). Bukti kualitatif : Siswa dapat dilihat dari meningkatnya nilai siswa seperti lebih bermina menjalani pembelajaran 2 . Siswa lebih berani berekspresi 3. Suasanabelajar lebih alami dan menyenangkan. Hal itu menunjukkan bahwa penggunaan Metode Struktural Analitik Sintetik). Dapat meningkatkan kemampuan menulis permulaan. Ini berarti hipotesis terbukti.

Kata kunci: perencanaan, pelaksanaan, observasi dan refleksi

\section{PENDAHULUAN}

Latar Belakang Masalah, Pembelajaran Bahasa Indonesia mencakup empat (4) keterampilan berbahasa, yakni: mendengar, berbicara, membaca, dan menulis. Salah satu keterampilan berbahasa yang cukup kompleks adalah menulis. Menulis merupakan kegiatan yang paling komplek untuk dipelajari dan diajarkan (Farris, 1993). ${ }^{1}$

Standarkompetensi bidang studi Bahasa Indonesia kelas 2 semester 1 menyebutkan bahwa aspek menulis permulaan meliputi menjiplak, menebalkan, mencontoh, melengkapi, dan menyalin. Kompetensi dasar yang seharusnya dikuasai adalah: (1) Menjiplak berbagai bentuk gambar, lingkaran, dan bentuk huruf; (2) Menebalkan berbagai bentuk gambar, lingkaran, dan bentuk huruf; (3) Mencontoh huruf, kata, atau kalimat sederhana dari buku atau papan tulis dengan benar; (4) Melengkapi kalimat yang belum selesai berdasarkan gambar; dan (5) Menyalin puisi anak sederhana dengan huruf lepas.

Berdasarkan pengamatan dalam proses belajar di kelas, dan hasil ulangan harian 1 peneliti mendapati bahwa siswa kelas $2 \mathrm{SD}$ Negeri 06 Perawang Barat masih ada beberapa siswa yang belum pandai menulis dan membaca dengan baik dan benar. Hal ini diduga disebabkan oleh rendahnya minat siswa untuk belajar aspek menulis dan membaca. Untuk itulah peneliti melakukan penelitian tindakankelas untuk bidang studi Bahasa Indonesia aspekmenulis.
Untuk tujuan itu, peneliti mencoba menyajikan pembelajaran Bahasa Indonesia aspek menulis dengan metode Struktural Analitik Sintetik (SAS). Siswadituntut untuk berlatih menulis permulaan dengan metode tersebut sehingga ada peningkatan kemampuan dalam menulis permulaan.

Namun demikian, dalam melaksanakan tugas di lapangan penulis mendapatkan beberapa permasalahan, yaitu:

1. Masih rendahnya kemampuan siswa dalam keterampilan menulis permulaan.

2. Banyaknya siswa yang belum mencapai kriteria ketuntasan minimal.

3. Proses belajar mengajar yang belum memakai metode yang tepat misalnyaStruktural Analitik Sintetik (SAS).

Dari uraian di atas, penulis merasakan perlu diadakan penelitian mengenai peningkatan kemampuan menulis permulaan dengan judul "Penggunaan Metode Struktural Analitik Sintetik (Sas) Untuk Meningkatkan Kemampuan Menulis dan Membaca Permulaan Pada Siswa Kelas 2 SDNegeri 06 Perawang Barat" (Penelitian Tindakan Kelas Pada Siswa Kelas 2 SD Negeri 06 Desa Perawang Barat, Kec. Tualang, Kab. Siak Tahun Pelajaran 2015-2016).

Deskripsikeadaan proses pembelajaran yang seperti di atas, diperolehhalhalsebagaiberikut :

1. Masih rendahnya kemampuan siswa dalam keterampilan menulis permulaan.

2. Banyaknya siswa yang belum mencapai kriteria ketuntasan minimal. 
3. Proses belajar mengajar yang belum memakai metode yang tepat misalnya Struktural AnalitikSintetik (SAS).

4. Media pembelajaran yang belum maksimal digunakan, sehingga kurang menarik minat siswa.

Agar penulisan karya tulis ilmiah ini lebih efektif, efisien dan terarah dan dapat dikaji. Maka dalam penelitian ini difokuskan pada, penggunaan metode SAS pada menulis permulaan siswa kelas 2 SDN 06 Perawang Barat. Mampu mengoperasikan penjumlahan dan pengurangan pada mata pelajaran Matematika.

Dari identifikasi dan pembatasan berbagai macam masalah yang ada, peneliti merumuskan masalah sebagai berikut: "Apakah Metode Struktural Analitik Sintetik (SAS) dapat meningkatkan kemampuan Siswa Kelas 2 SDN 06 Perawang Barat dalam menulis permulaan".

Penelitian bertujuan untuk :Mengetahui efektifitas penggunaan metode Struktural Analitik Sintetik (SAS) di kelas 2 SDN 06 Perawang Barat

1. Mengukur kemampuan siswa kelas 2 SDN 06 Perawang Barat meningkatkan kemampuan siswa dalam menulis permulaan dengan metode Struktural Analitik Sintetik (SAS).

2. Melatih keterampilan menulis siswa kelas2 SDN 06 Perawang Barat, sehingga memiliki kemampuan dasar yang tepat dalam pembelajaran menulis Bahasa Indonesia

Metode yang akan digunakan dalam penelitian adalah jenis Penelitian Tindakan Kelas (PTK). Pertimbangan yang mendasari penelitian metode ini, karena langkah-langkah penelitian cukup sederhana, sehingga mudah dipahami dan dilaksanakan oleh peneliti. Dengan kata lain, model dan tekhnik PTK tidak bersifat kaku, sehingga sesuai dengan kemampuan peneliti dan alokasi yang tersedia

Menurut Depdikbud, (1999 : 9-10). ${ }^{12}$ Salah satu tujuan dari PTK adalah:

PTK dilaksanakan demi perbaikan dan/atau peningkatan praktek pembelajaran secara berkesinambungan, yang pada dasarnya melekat pada terlaksananya misi profesional pendidikan yang diemban guru. Oleh karena itu, PTK merupakan salah satu cara strategis dalam memperbaiki dan meningkatkan layanan pendidikan yang harus diselenggarakan dalam konteks, dan/atau dalam peningkatan kualitas program sekolah secara keseluruhan, dalam masyarakat yang cepat berubah

Dari definisi di atas dapat disimpulkan, penelitian tindakan kelas adalah penelitian tindakan yang dilaksanakan oleh guru di dalam kelas dengan tujuan untuk memperbaiki kinerjanya dan meningkatkan hasil belajar siswa. Pendekatan yang digunakan dalam penelitian ini adalah pendekatan Kualitatif yaitu menggambarkan masalah sebenarnya yang ada di lapangan, kemudian direfleksikan dan dianalisis berdasarkan teori menunjang dilanjutkan dengan pelaksanaan tindakan di lapangan. Pendekataan Kualitatif dalam penelitian ini digunakan untuk menelusuri dan mendapatkan gambaran secara jelas tentang situasi kelas dan tingkah laku siswa selama proses pembelajaran berlangsung. Penelitian Tindakan Kelas dilaksanakan secara bersiklus. Pembelajaran dilakukan di kelas 2 SDN 06 perawang barat.

\section{METODE PENELITIAN TINDAKAN KELAS}

Jenis penelitian yang digunakan dengan Penelitian Tindakan Kelas (PTK) karena ingin menerapkan pembelajaran untuk meningkatkan kemampuan siswa kelas 2 dalam mengoperasionalkan penjumlahan dan pengurangan bilangan dengan alat bantu bendabenda kongkrit di sekitar sekolah

Desain penelitian yang dirancang dalam penelitian ini mengacu padamodel yang digunakan yaitu model Kemmis dan Mc Taggart. Desain Kemmis inimenggunakan model yang dikenal sistem spiral refleksi. Dalam model tersebutterdapat empat kegiatan utama yang ada pada setiap siklus, yaitu: (a)perencanaan,(b) tindakan/observasi, dan (c) refleksi.

Pelaksanaan PTK dimulai dari siklus pertama yang terdiri dari tigakegiatan. Apabila sudah diketahui letak keberhasilan dan hambatan dari tindakanyang telah dilaksanakan pada siklus pertama, maka peneliti dapat menentukanrancangan untuk siklus kedua. Kegiatan pada siklus kedua biasanya berupakegiatan yang sama dengan kegiatan sebelumnya apabila ditujukan untukmengulangi kesuksesan atau untuk menyakinkan. Akan tetapi, pada umumnyakegiatan kedua mempunyai 
berbagai tambahan perbaikan dari tindakan terdahuluyang ditujukan untuk memperbaiki berbagai hambatan atau kesulitan yangditemukan pada siklus pertama. Dengan menyusun rancangan siklus kedua, makaguru dapat melanjutkan dengan tahap-tahap kegiatan pada siklus kedua. Jikasiklus kedua telah selesai dilaksanakan guru dapat melanjutkan merancangkegiatan untuk siklus ketiga dan seterusnya.

Alur siklus PTK yang diterapkan pada penelitian ini adalah mengadaptasi dari model Kemmis dan Mc. Taggart. Dalam penelitian ini , model Kemmis dan Taggart menekankan pada 4 proses yaitu : (1) perencanaan, (2) pelaksanaan, dan observasi dan (3) refleksi. Keempat proses itu dibentuk dalam sebuah siklus proses pembelajaran. Adapun dalam penelitian yang singkat ini, maka penulis merencanakan untuk melaksanakan proses PBM diperkirakan sekurang-kurangnya akan dilaksanakan dalam 3 siklus berkesinambungan. Adapun satu siklus PBM membutuhkan alokasi waktu 2 x 35 menit atau 1 kali pertemuan pembelajaran.

Secara lebih konkret, berikut langkah-langkah penelitian tindakan desain Depdiknas, $2006^{13}$ :

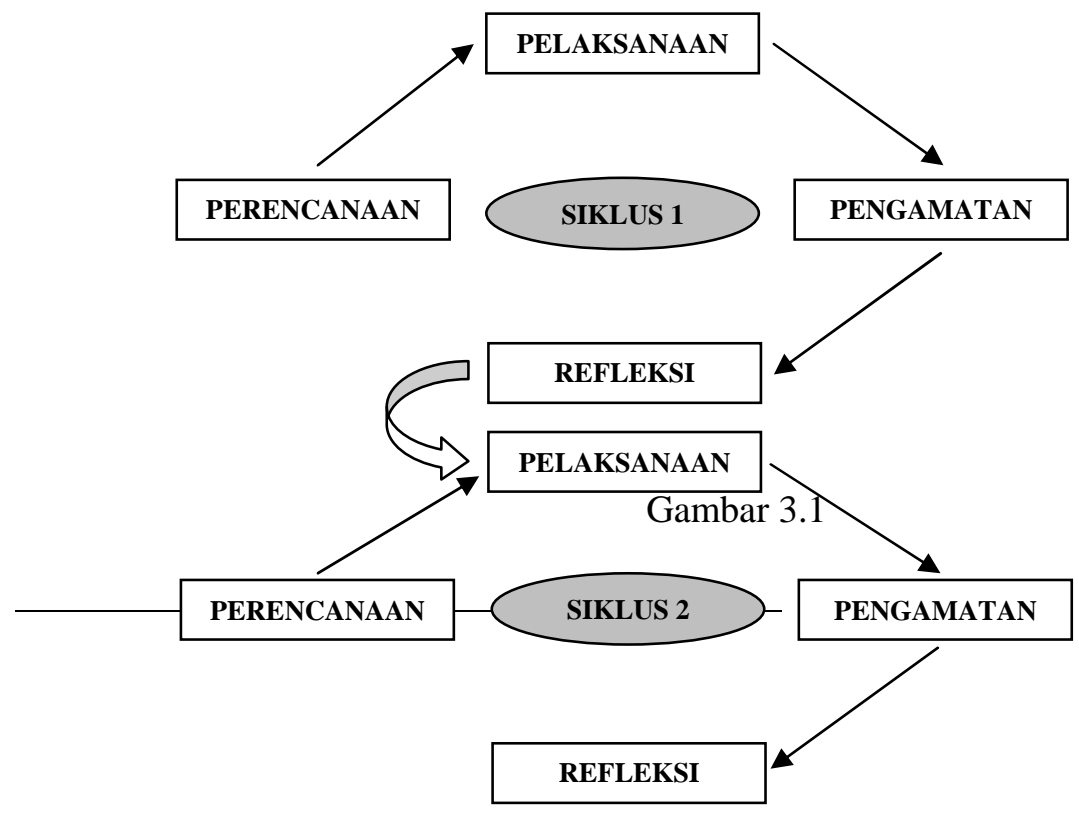

Alur Penelitian Tindakan Kelas Desain Kemmis \& Mc.Tagart

Subyek penelitian adalah siswa-siswi Kelas 2SD Negeri 06 Perawang Barat. yang berjumlah 26 orang, terdiri dari 13 siswa lakilaki dan 13 siswa perempuan, padapembelajaran bahasa Indonesia.

Sumber data pada penelitian ini adalah seluruh siswa kelas 2SD Negeri 06 Perawang Barat. Fokus penelitian menekankan pada penggunaan media kongkret dalam meningkatkan kemampuan megoperasikan penjumlhan bilangan di SD Negeri 06 perawang barat Tahun Pelajaran 2015/2016 Semester I bulan September.

Penentuan jadwal waktu Penelitian Tindakan Kelas di SD Negeri 06 perawang barat Tahun Pelajaran 2015/2016 Semester I. Penelitian ini dilaksanakan pada bulan
September semester 1 Tahun Pelajaran 2015/2016, sesuai dengan (RPP) Rencana Pelaksanaan Pembelajaran yang telah ditetapkan.

Tekhnik pengumpulan data dilakukan berdasarkan bentuk data yang diperoleh . Untuk memperoleh data yang diinginkan dalam pembelajaran Bahasa Indonesia khususnya kemampuan menulis permulaaan dilakukan dengan teknik Observasi, diskusi dan evaluasi hasil belajar yang hasilnya akan dilaksanakan dalam bentuk skor. Sebelum dilaksanakan pelaksanaan tindakan kelas peneliti mengidentifikasi masalah pembelajaran Bahasa Indonesia Kelas I dilanjutkan dengan upaya 
pemecahan masalah yang dihadapi Guru dan siswa.

Instrumen yang digunakan dalam penelitian ini terdiri dari:

Silabus adalah penjabaran aspek yang ada dalam kurikulum pembelajaran. adapun lembar silabus pada penelitian ini terdapat pada lampiran.

RPP adalah ancangan pembelajaran yang merupakan penjabaran dari silabus yang digunakan.Adapun lembar RPP dalam penelitian ini terdapat pada lampiran.

Soal tes evaluasi terlampir.Tes ini disusun berdasarkan tujuan pembelajaran yang akan dicapai, digunakan untuk mengukur hasil belajar mata pelajaran Bahasa Indonesia pokok bahasan menulis permulaan. Tes formatif ini diberikan setiap akhir tindakan dalam setiap siklus. Bentuk soal yang diberikan adalah pilihan peneliti.Analisis ini digunakan untuk memilih soal yang baik dan memenuhi syarat digunakan untuk mengambil data.

Untuk mengetahui keefektivan suatu metode dalam kegiatan pembelajaran perlu diadakan analisa data. Pada penelitian ini menggunakan teknik analisis deskriptif kualitatif, yaitu suatu metode penelitian yang bersifat menggambarkan kenyataan atau fakta sesuai dengan data yang diperoleh dengan tujuan untuk mengetahui prestasi belajar yang dicapai siswa juga untuk memperoleh respon siswa terhadap kegiata pembelajaran serta aktivitas siswa selama proses pembelajaran.

Untuk mengalisis tingkat keberhasilan atau persentase keberhasilan siswa setelah proses belajar mengajar setiap putarannya dilakukan dengan cara memberikan evaluasi berupa soal tes tertulis pada setiap akhir putaran.

Analisis ini dihitung dengan menggunakan statistik sederhana yaitu:

Peneliti melakukan penjumlahan nilai yang diperoleh siswa, yang selanjutnya dibagi dengan jumlah siswa yang ada di kelas tersebut sehingga diperoleh rata-rata tes formatif dapat dirumuskan:

$$
\begin{aligned}
\bar{X}=\frac{\sum X}{\sum N} & \\
\text { Dengan }: \bar{X} & =\text { Nilai rata-rata } \\
\Sigma \mathrm{X} & =\text { Jumlah semua nilai siswa } \\
\Sigma \mathrm{N} & =\text { Jumlah siswa }
\end{aligned}
$$

a. Untuk Ketuntasan Belajar

Ada dua kategori ketuntasan belajar yaitu secara perorangan dan secara klasikal. Berdasarkan petunjuk pelaksanaan belajar mengajar kurikulum 1994 (Depdikbud, 1994) ${ }^{14}$, yaitu seorang siswa telah tuntas belajar bila telah mencapai skor $65 \%$ atau nilai 65 , dan kelas disebut tuntas belajar bila di kelas tersebut terdapat $85 \%$ yang telah mencapai daya serap lebih dari sama dengan $65 \%$. Untuk menghitung persentase ketuntasan belajar digunakan rumus sebagai berikut:

Untuk mengukur ketercapaian tujuan pembelajaran dan memperoleh data data mengenai ketuntasan siswa setelah pelaksanaan evaluasi diukur dengan cara:

$$
\begin{array}{ll}
\bar{X}=\frac{\sum X}{\sum N} & : \bar{X} \quad=\text { Nilai rata-rata }
\end{array}
$$

A. Indikator Keberhasilan Indikator keberhasilan yang dijadikan acuan dalam setiap tindakan dalam penelitian ini digunakan rumus sebagaimana dikemukakan oleh Solchan T. W, dkk (2008:135) ${ }^{15}$, yaitu :

Jumlah Perolehan Nilai

Tingkat penguasaan $=$

--- $100 \%$

\section{Jumlah Siswa}

Patokan pengukuran dengan tahapan pencapaian penguasaan kemampuan siswa digunakan kriteria penilaian prosentase, adalah :

$$
\begin{array}{ll}
81 \%-100 \% & : \text { Baik sekali } \\
61 \%-80 \% & : \text { Baik } \\
41 \%-60 \% & : \text { Cukup } \\
21 \%-40 \% & : \text { Kurang } \\
0 \%-20 \% & : \text { Kurang sekali }
\end{array}
$$


Untuk menentukan nilai penapsiran digunakan kriteria penilaian dengan lima katagori, yaitu : A Nilai angka 5 (sangat baik)
B Nilai angka 4 (baik)
C Nilai angka 3 (cukup)
D Nilai angka 2 (kurang)
E Nilai angka 1 (kurang sekali)

B. Prosedur/Pelaksanaan Penelitian

Prosedur Penelitian Tindakan Kelas ini menggunakan siklus berulang, dengan tiap siklus dilaksanakan sesuai dengan perubahan yang ingin dicapai, seperti yang telah didesain dalam faktor yang telah diselidiki. Dari evaluasi dan observasi awal, maka dalam refleksi ditetapkanlah bahwa tindakan yang dipergunakan untuk meningkatkan kualitas pertemanan siswa dalam pembelajaran Bahasa Indonesia adalah melalui metode SAS. Berdasarkan hasil refleksi awal tersebut maka dilaksanakanlah PTK dengan prosedur : perencanaan, pelaksanaan, pengamatan, dan refleksi. Secara lebih rinci prosedur Penelitian Tindakan Kelas tiap siklus ini dapat dijabarkan sebagai berikut:

Secara garis besar kegiatan yang dilakukan pada setiap siklus penelitian adalah sebagai berikut:

1. Pelaksanaan Siklus 1

a. Perencanaan Tindakan 1

Setelah peneliti berhasil menganalisis permasalahan pembelajaran yang ditemukan, maka hasil analisis dijadikan bahan untuk merencanakan perbaikan pembelajaran. Adapun tahapannya adalah:

1) Menyiapkan rencana perbaikan pembelajaran

2) Menyiapkan media berupa teks lagu $\mathrm{ABC}$

3) Menyiapkan media berupa kartu huruf, kartu kata, dan contoh kalimat sederhana.

4) Menyiapkan lembar kerja siswa (LKS)

5) Menyiapkan alat evaluasi

6) Menyiapkan lembar observasi

b. Pelaksanaan Tindakan I
1) Guru mengawali kegiatan pembelajaran dengan apersepsi berupa tanya jawab.

2) Guru menyampaikan tujuan pembelajaran

3) Guru mengajak siswa menyanyikan lagu $\mathrm{ABC}$

4) Guru melakukan pendalaman materi dengan tanya jawab.

5) Siswa dibimbing guru membaca kartu huruf dan kata serta kalimat sederhana di papan tulis.

6) Siswa mencontoh huruf, kata, dan kalimat sederhana.

7) Siswa mengerjakan LKS

8) Pengamat mengamati dan mencatat proses pembelajaran dalam lembar observasi

c. Observasi Tindakan I

Selama proses belajar mengajar peneliti dibantu teman sejawat sebagai observer melakukan pengamatan dengan lembar observasi. Dalam observasi ini observer mencatat ada 6 siswa $(44,44 \%)$ telah bersungguh-sungguh mengikuti pembelajaran dan dapat menjawab pertanyaan dengan benar.

d. Refleksi Tindakan I

Refleksi dilakukan untuk menemukan kegiatan-kegiatan yang perlu diperbaiki serta menetapkan solusinya. Hasil refleksi terhadap kegiatan pembelajaran pada siklus pertama adalah sebagai berikut. Siswa mengalami kebosanan dalam pembelajaran Banyak siswa mengalami kesulitan dalam menulis. Hasil mengerjakan tugas masih jauh dari harapan. Hasil belajar siswa yang memenuhi KKM baru 44,44\%.

Berdasarkan rekomendasi dari observer, solusi untuk mengatasi masalah tersebut adalah mencari metode atau strategi pembelajaran yang lebih menarik. Untuk itu perlu diadakan perbaikan II agar lebih meningkatkan minat siswa dan hasil belajar.

2. Pelaksanaan Siklus II

a. Perencanaan Tindakan II

1) Menyiapkan rencana perbaikan pembelajaran 
2) Menyiapkan media pembelajaran berupa teks lagu tingginya huruf

3) Menyiapkan media berupa contoh kalimat dengan metode SAS

4) Menyiapkan lembar kerja siswa (LKS)

5) Menyiapkan lembar observasi

6) Menyiapkan lembar evaluasi

b. Pelaksanaan Tindakan II

1) Guru mengawali kegiatan pembelajaran dengan apersepsi berupa tanya jawab.

2) Guru menyampaikan tujuan pembelajaran

3) Guru mengajak siswa menyanyikan lagu Tingginya Huruf.

4) Siswa dibimbing guru membaca kalimat sederhana

5) Siswa mencontoh kalimat sederhana

6) Siswa mengerjakan LKS

7) Siswa mengerjakan soal tes akhir

8) Pengamat mengamati dan mencatat proses pembelajaran dalam lembar obsercasi.

\section{HASIL PENELITIAN DAN PEMBAHASAN}

Penelitian ini dilaksanakan dalam 2 siklus yang sesuai dengan tingkat keberhasilan yang dicapai oleh siswa ataupun guru. Setiap siklus dilakukan satu tindakan yang dilaksanakan dalam kegiatan belajar mengajar (KBM) dengan durasi 2 x 35 menit. Setiap siklus terdiri dari tahapan perencanaan, tindakan, observasi dan refleksi. Adapun pengukuran terhadap hasil belajar, dilakukan dengan cara memberikan tugas dalam proses dan disetiap kegiatan pembelajaran diakhiri dengan tes akhir.

Observasi awal dilakukan oleh peneliti selama proses pembelajaran sehingga ditemukan masalah yang kemudian masalah tersebut dicarikan solusi/pemecahannya dengan cara dilakukan penelitian. Dalam melaksanakan penelitian ini, peneliti dibantu oleh teman sejawat sebagai observe, yang tugasnya memberi informasi dan data perkembangan siswa selama dilakukan upaya perbaikan pembelajaran. Adapun hasil dari setiap tindakan perbaikan dipakai sebagai bahan refleksi, untuk menentukan perlu tidaknya diadakan tindakan perbaikan berikutnya. c. Observasi Tindakan II

$$
\text { Selama proses belajar }
$$
mengajar peneliti dibantu teman sejawat sebagai observer melakukan pengamatan dengan lembar observasi. Data hasil observasi terlibat bahwa minat siswa dalam mengikuti pembelajaran meningkat secara tajam. Dari 6 siswa pada siklus I menjadi 13 siswa, meningkat $52,78 \%$.

d. Refleksi Tindakan II Dari data yang telah dikumpulkan lalu diadakan analisis, maka peneliti dan observer berdiskusi dan sepakat bahwa metode Struktural Analitik Sintetik (SAS) sangat tepat digunakan dalam pembelajaran menulis permulaan. Terbukti $97,22 \%$ siswa berminat dan antusias untuk mengikuti pembelajaran. dibandingkan pada siklus I sebanyak 6 siswa $(44,44 \%)$ dapat memenuhi KKM, meningkat $52,78 \%$.

1. Pelaksanaan Siklus I

a. Perencanaan Tindakan I

Pelaksanaan tindakan I dimulai dengan kegiatan awal yaitu persiapan kelas. Dilakukan 15 menit sebelum pelaksanaan pembelajaran. Persiapan yang diperlukan meliputi: menyiapkan kartu huruf, hartu kata, dan kalimat. Selain itu juga disiapkan teks musik pengiring/pendukung. Dipersiapkan pula meja dan kursi untuk pengamat, rencana pembelajaran, dan lembar observasi.

b. Pelaksanaan Tindakan I

Pelaksanaan Kegiatan Belajar Mengajar (KBM) berlangsung dengan 3 kegiatan, yaitu pendahuluan, kegiatan inti, dan penutup.

1) Kegiatan Pendahuluan

Dalam

kegiatan

pendahuluan, peneliti memotivasi siswa agar lebih siap mengikuti pembelajaran. Selanjutnya peneliti 
menjelaskan kompetensi dasar dari pembelajaran.

2) Kegiatan Inti

Dalam kegiatan inti, peneliti mengajak siswa untuk menyanyikan lagu ABC, membaca kartu huruf, kata, dan kalimat. Kemudian siswa menyalin kalimat dari papan tulis, dan mengerjakan LKS. Di akhir kegiatan inti, siswa diberi kesempatan untuk menanyakan hal-hal yang belum dimengerti berkaitan dengan pembelajaran dan mendapat umpan balik.

3) Kegiatan Penutup

Dalam kegiatan penutup peneliti menanyakan perasaan siswa selama mengikuti pembelajaran. Hal ini dimaksudkan untuk mendapatkan masukan dari siswa dan sebagai refleksi terhadap pembelajaran.

c. Observasi Tindakan I

Adapun setelah kegiatan belajar mengajar selesai, guru dan pengamat mencermati dan menganalisa Kegiatan Belajar Mengajar (KBM) tersebut. Temuan yang di dapat oleh pengamat adalah guru sudah melaksanakan KBM sesuai waktu yang ditentukan. Pelaksanaan pembelajaran juga sesuai dengan rencana persiapan.

d. Refleksi Tindakan I

Refleksi dilakukan untuk menemukan kegiatan-kegiatan yang perlu diperbaiki serta menetapkan solusinya. Hasil refleksi terhadap kegiatan pembelajaran pada siklus pertama adalah sebagai berikut. Siswa mengalami kebosanan dalam pembelajaran. Hanya beberapa siswa yang nampak aktif dalam pembelajaran. Hal ini menunjukkan bahwa partisipasi siswa kurang. Hasil mengerjakan tugas masih jauh dari harapan. Masih banyak siswa yang nilainya belum mencapai KKM. Hasil observasi pengamat menyimpulkan bahwa siswa kurang tertarik dengan alat peraga.Solusi untuk mengatasi masalah tersebut adalah mencari alat peraga yang lebih menarik minat siswa.

2. Pelaksanaan Siklus II

a. Perencanaan Tindakan II

Peneliti menyiapkan alat peraga kartu huruf, kata, kalimat serta menyiapkan alat peraga tambahan berupa gambar-gambar yang sesuai dengan kalimat yang akan dicontoh siswa. Selain itu juga menyiapkan teks lagu yang berisi materi aturan baku menulis huruf lepas, dilengkapi dengan instrument musik yang digemari siswa.

b. Pelaksanaan Tindakan II

Kegiatan belajar mengajar meliputi 3 kegiatan yaitu pendahuluan, inti, dan penutup.

1) Kegiatan Pendahuluan

Dalam

kegiatan

pendahuluan, peneliti memotivasi siswa agar lebih siap mengikuti pembelajaran. Selanjutnya peneliti menjelaskan kompetensi dasar dari pembelajaran.

2) Kegiatan Inti

Dalam kegiatan inti, peneliti mengajak siswa untuk menyanyikan lagu Tinggi Huruf, membaca kartu huruf, kata, dan kalimat. Kemudian siswa menyalin kalimat dari papan tulis, dan mengerjakan LKS. Di akhir kegiatan inti, siswa diberi kesempatan untuk menanyakan hal-hal yang belum dimengerti berkaitan dengan pembelajaran dan mendapat umpan balik.

3) Kegiatan Penutup

Dalam kegiatan penutup peneliti menanyakan perasaan siswa selama mengikuti pembelajaran. Hal ini dimaksudkan untuk mendapatkan masukan dari siswa dan sebagai refleksi terhadap pembelajaran.

c. Observasi Tindakan II
Peneliti
telah memiliki
kemampuan yang baik untuk menjelaskan metode Struktural Analitik Sintetik menggunakan media yang sudah disiapkan dengan matang. Siswa kelihatan sangat antusias dalam 
belajar, juga terlihat sangat menikmati proses belajar.

d. Refleksi Tindakan II

Hasil refleksi terhadap kegiatan pembelajaran pada siklus kedua adalah sebagai berikut. Kegiatan pembelajaran berlangsung secara sangat baik, siswa lebih berminat menjalani pembelajaran, lebih berani berekspresi, suasana belajar alami dan menyenangkan. Para siswa aktif melakukan tugas-tugasnya dan hasil tes pun mencapai KKM.

Penelitian ini menunjukkan bahwa pemilihan Metode Struktural Analitik Sintetik menggunakan alat peraga berupa gambar dapat meningkatkan minat belajar Bahasa Indonesia dan meningkatkan kemampuan siswa khususnya dalam menulis permulaan. Dan hasil penelitian ini membuktikan bahwa peningkatan prestasi belajar siswa tidak lepas dari ketepatan dalam memakai metode pembelajaran.

A. Pembahasan Hasil Penelitian

Setelah melalui tindakan perencanaan, pelaksanaan, observasi dan refleksi pada masing-masing siklusnya. Maka selama 2 siklus yang berjalan dapat diperoleh hasil sebagai berikut:

1. Hasil Penelitian Siklus I

Pada penelitian tindakan kelas pada siklus I, guru menjelaskan Metode Strukturak Analitik Sintetik dengan satu arah Dalam menyampaikan proses pembelajaran tahap ini guru sudah berusaha mengajar dengan komunikatif. Dan memang beberapa siswa terlihat antusias mendengarkan. Dari analisa kegiatan pembelajaran pada siklus I didapatkan data sebagai berikut:

a. Faktor Siswa

Pada awal kegiatan siswa mulai terlihat berminat mengikuti pembelajaran dengan menjawab pertanyaan pre tes lisan guru tentang aturan baku penulisan huruf. Ada sekitar 8 anak (32\%) siswa yang terlihat sangat antusias, dan aktif mengikuti kegiatan pembelajaran. Adapun siswa yang lain, terlihat kurang berminat bahkan masih banyak siswa yang kurang berkonsentrasi.

b. Faktor Guru

Dari hasil pengamatan observer menunjukkan bahwa guru masih belum optimal dalam menggunakan alat peraga. Dan belum sepenuhnya menguasai metode pembelajaran yang digunakan.

2. Hasil Belajar

Dari hasil tes akhir, menunjukkan nilai yang telah memenuhi KKM (Kriteria Ketuntasan Minimal) hanya 8 siswa dan ada 16 anak yang belum memenuhi Kriteria Ketuntasan Minimal/KKM namun berminat. Berikut tabel nilai hasil belajar pada siklus I dan table kriteria hasil belajar siswa pada siklus

Analisis terhadap hasil observasi dan hasil tes akhir dijadikan sebagai bahan untuk menentukan tindakan selanjutnya. Setelah itu antara penulis, teman sejawat dan supervisor mengadakan refleksi dan diskusi. Dalam diskusi tersebut diperoleh catatan-catatan penting sebagai berikut:

a) Guru harus mampu meningkatkan kualitas proses Kegiatan Belajar Mengajar (KBM) dengan mengembangkan berbagai macam metode pengajaran yang menarik bagi siswa.

b) Guru harus mampu membuat alat peraga yang cocok dengan materi pembelajaran. Alat peraga yang bagus akan menarik minat siswa agar lebih fokus terhadap materi.

c) Guru harus mampu menciptakan suasana pembelajaran yang menyenangkan.

3. Hasil Penelitian Siklus II

Berdasarkan hasil refleksi pada Siklus I maka perbaikan pembelajaran untuk siklus II dilaksanakan dan diperoleh hasil sebagai berikut:

\section{a. Faktor Siswa}

Suasana Kegiatan Belajar Mengajar (KBM) di kelas, tampak sangat menyenangkan dan sangat antusias ada 13 siswa $(97,22 \%)$ sudah bersungguh-sungguh mengikuti pembelajaran dan antusias dalam 
mengerjakan tugas/latihan. Hanya ada satu siswa yang kurang bersungguh-

sungguh $(2,78 \%)$.

Berikut adalah data minat dan keaktifan siswa.

Tabel. 4.2

Minat dan Keaktifan Siswa

\begin{tabular}{|c|c|c|}
\hline Klasifikasi & Frekuensi & Prosentase (\%) \\
\hline B & 13 & $97,22 \%$ \\
\hline $\mathrm{C}$ & 1 & $2,78 \%$ \\
\hline $\mathrm{K}$ & - & - \\
\hline$\sum$ & 14 & $100 \%$ \\
\hline
\end{tabular}

Keterangan:

1) $\mathrm{B}=$ artinya baik, yaitu siswa yang sungguh-sungguh dalam mengikuti pembelajaran dan dapat menjawab pertanyaan guru dengan mayoritas jawaban benar.

2) $\mathrm{C}=$ artinya cukup, yaitu siswa yang sungguh-sungguh dalam mengikuti pembelajaran tetapi tidak dapat menjawab pertanyaan guru dengan mayoritas benar atau dapat menjawab pertanyaan guru tetapi tidak bersungguh-sungguh (konsentrasi) saat Kegiatan Belajar Mengajar.

3) $\mathrm{K}=$ artinya kurang, yaitu siswa yang tidak bersungguh-sungguh dalam mengikuti Kegiatan Belajar Mengajar dan tidak dapat menjawab pertanyaan guru.

b. Faktor Guru

Pada siklus ini guru memberi kesempatan pada siswa untuk bereksplorasi pada materi yang dikenal oleh siswa, Guru juga berusaha menggunakan alat peraga yang menarik sehingga siswa mampu dan antusias dalam KBM.

4. Hasil Belajar Siswa

Bila dilihat perbandingan antara siklus I dan siklus II menunjukkan peningkatan yang sangat signifikan dan menggembirakan. Dari hasil belajar 14 siswa sudah memenuhi KKM $(97,22 \%)$, meningkat $52,78 \%$, jika dibandingkan dengan siklus I. Berikut ini tabel nilai hasil belajar pada siklus II dan tabel kriteria hasil belajar siswa pada siklus II. Serangkaian tindakan telah dilakukan dengan baik, sehingga menghasilkan perbaikan nilai yang signifikan. Hal ini Nampak pada tabel perbandingan nilai hasil belajar dan tabel persentase ketuntasan belajar siswa sebelum tindakan, siklus I, dan siklus II

\section{KESIMPULAN}

\begin{abstract}
Berdasarkan observasi dan pengolahan data terlihat peningkatan pemahaman yang dapat dilihat dari meningkatnya nilai siswa.

Bukti kuantitatif :
\end{abstract}

- Siklus pertama: nilai anak yang mencapai KKM 2 anak $(44,44 \%)$, nilai anak yang kurang dari KKM 12 anak $(55,55 \%)$.

- Siklus kedua: nilai anak yang mencapai KKM 14 anak $(97,22 \%)$.
- Terjadi peningkatan $52,78 \%$ pada siklus kedua (pembelajaran dengan Metode Struktural Analitik Sintetik).

Bukti kualitatif :

- Siswa lebih berminat menjalani pembelajaran

- Siswa lebih berani berekspresi

- Suasana belajar lebih alami dan menyenangkan

Hal itu menunjukkan bahwa penggunaan Metode Struktural Analitik Sintetik). Dapat 
meningkatkan kemampuan menulis permulaan. Metode Struktural Analitik Sintetikhanyalah satu Ini berarti hipotesis terbukti.

Guna mencapai hasil pembelajaran yang lebih baik dan bermakna bagi siswa, guru sebaiknya memiliki keterampilan untuk memilih dan menggunakan metode untuk memungkinkan dicapainya pembelajaran yang lebih optimal. Dalam proses Kegiatan Belajar Mengajar Bahasa Indonesia, terutama keterampilan untuk menulis, guru hendaknya lebih rajin dan aktif untuk membuat alat peraga yang menarik minat siswa, sehingga siswa menjadi optimal dalam menerima materi pembelajaran.

Kami mengajak para guru untuk menindaklanjuti/menggunakan hasil penelitian ini dengan baik dan dijadikan motivasi agar mampu melakukan penelitian tindakan kelas.

dari sekian banyak metode atau strategi pembelajaran yang dapat digunakan. Para guru dapat mencari metode atau strategi pembelajaran yang lain.

Apabila guru ingin mengetahui masalah yang dihadapi dalam pembelajaran, maka guru harus melaksanakan refleksi pada aktifitas pembelajaran yang dilaksanakan.Tidakan dan masalah yang tidak dapat diselesaikan dalam proses belajar mengajar, apabila guru dapat menentukan solusi yang dianggap tepat untuk mengatasi masalah tersebut. Teknik yang dipilih guru dapat dijadikan solusi alternatif apabila guru dapat memfokuskan secara pasti. Data hasil pelaksanaan PTK dapat dijadikan bukt iempiris apabila guru ingin menilai keberhasilan. 


\section{DAFTAR PUSTAKA}

Farris. (1993). StrategiBelajarMengajar. Jakarta:

BalaiPustaka.

Depdikbud, 1994,

PenelitianTindakanKelas,Jakarta ;

Unipersitas Terbuka.

Depdiknas. 2006. Kurikulum Tingkat

SatuanPendidikan. Jakarta :Depdiknas.

Purwanto, M Ngalim_DjeniahAlim. 2003.

MetodologiPengajaranBahasa Indonesia di SekolahDasar.Bandung ;PenerbitAngkasa.

Suhandin. 2000, KamusUmumBahasa Indonesia, Jakarta :BalaiPustaka.

Djauzak. 1998,

BahasadanSastradalamGamitanPendidikan .; Jakarta.

Roestiyah. (1988). StrategiBelajarMengajar. Jakarta: RinekaCipta.
Semi, N. Atar. (2007). Dasar-

DasarKeterampilanMenulis. Padang: Angkasa Raya.

Solchan T. W, dkk. (2008). PendidikanBahasa Indonesia di SD. Jakarta:Universitas Terbuka.

St. Y. Slamet. (2008). DasarDasarKeterampilanBerbahasa Indonesia. Surakarta: UNS Press

Tarigan, Henry Guntur. (1986).

PengajaranSemantik. Bandung: Penerbit Angkasa.

Supriyadi. (1996).

PengajaranAnalisisKesalahanBerbahasa. Bandung: PenerbitAngkasa.

Sabana. (1989).

MetodeStrukturalAnalitikSintetik (SAS).

Bandung:PenerbitAngkasa. 